PAKó LÁSZLó*

\title{
PRÓKÁTOROK KOLOZSVÁRON A 16. SZÁZAD UTOLSÓ ÉVTIZEDEIBEN
}

\author{
Kulcsszavak: Erdélyi Fejedelemség, kora újkori Kolozsvár, városi bíráskodás, jogtudó \\ értelmiség, prókátorok
}

A 16. század végi Kolozsváron számos prókátor tevékenysége adatolható, az eddigi kutatás mégis csupán Igyártó György ténykedéséről adott számot. ${ }^{1} \mathrm{Az}$ alábbiakban a város levéltárában fennmaradt adatokra támaszkodva rövid áttekintést adunk a kolozsvári prókátorság intézményéről, majd pedig egyes személyi karrierek példáján szemléltetjük azokat a lehetőségeket, melyeket a kora újkori prókátorság nyújtott. Akárcsak más városok bírósági gyakorlatában, Kolozsvár esetében is találunk prókátorokat, akik kizárólag magánszemélyek ügyvédjeiként tevékenykedtek, és olyanokat akik a város peres ügyeiben is eljártak.

\section{PRÓKÁTOROK A VÁROS SZOLGÁLATÁBAN}

Városi prókátor alkalmazása bevett szokás volt a kora újkori erdélyi városi bíráskodási gyakorlatban. A gyulafehérvári tanács például 1588-ban a magánszemélyek prókátoraként is tevékenykedő Sárdi Miklós deákot fogadta városi prókátornak, ${ }^{2}$ 1614-ben pedig azt a Bun Lukácsot, aki a 17. század első felének legtöbbet foglalkoztatott gyulafehérvári ügyvédje volt. ${ }^{3}$

* Pakó László, dr. (1980), történész, az Erdélyi Múzeum-Egyesület Kutatóintézetének tudományos munkatársa. Kutatási területei az erdélyi fejedelemség kori város-, intézmény-, jog- és társadalomtörténet, különösen Kolozsvár város kora újkori bíráskodási gyakorlata és bủnöző társadalma; kora újkori erdélyi jogtudó értelmiség; város és nemesség a kora újkori Erdélyben. Fontosabb munkái: Kényszer vagy erkölcsi romlottság? Csecsemógyilkosságok Kolozsvárt a 16. század utolsó évtizedében. Korunk, 2005/3; Városi polgár-vármegyei nemes? Nemesek ingatlanszerzése Kolozsváron a fejedelemség korában = A reneszánsz Kolozsvár. Szerk. Kovács András-Kovács Kiss Gyöngy. Kolozsvár, 2009; A városi közügyigazgatók Kolozsvár 16. század végi birósági gyakorlatában. Erdélyi Múzeum $\operatorname{LXXIV(2012).3.~sz.~}$

1 Kiss András: Farsangolás Kolozsvárt-1582-ben = Uó: Források és értelmezések. Kriterion, Buk., 1994. 103-109; PAкó László: A korrupt boszorkányüldözó. Igyártó György prókátori tevékenységéról. Erdélyi Múzeum LXXIII(2011). 3-4. sz. 97. (a továbbiakban PAкó 2011)

2 Gyulafehérvár város jegyzőkönyvei. Közzéteszi Kovács András. EME, Kvár, 1998 (Erdélyi Történelmi Adatok VI. 2). 9, 17. (a továbbiakban GyJk) - Sárdi szintén 1588-ban Mészáros Gergely - Báthory Boldizsár marosigeni jobbágya és a település bírója - fiának, Istvánnak volt ügyvédje, aki Gyulafehérvár külvárosában lévő házát és két szőlőjét próbálta per útján visszaszerezni. Az erdélyi káptalan jegyzőkönyvei. 1222-1599. Mut, jegyz, reg. Bogdáni Zsolt-Gálfi Emőke. EME, Kvár, 2006 (Erdélyi Történelmi Adatok VIII. 1). 524, 577, 779, 789. sz. (a továbbiakban ErdKáptJk)

3 „Mivelhogy Bun Lukács a város prókátora” GyJk 300. Múködésére 1603-tól (bizonyosan korábban is tevékenykedett már, de a törvénykezési jegyzőkönyvek elkallódtak) 1621. júniusáig vannak adatok. 
Neve feltűnik a negyven tagú városi tanács listáján, 1613-tól pedig többször beválasztották a 12 tagú felső tanácsba is. ${ }^{4}$ Már első adatolt fellépései során fontos városi személyek voltak a megrendelői: 1604-ben Mészáros Mátyás városbíró, 1605-ben pedig az alsó tanács testületileg fogadta meg prókátornak. A városbírák képviselőjeként mindig olyan bűncselekmények - mérgezés, hatósági személy megtámadása, nőtlen paráznaság és teherbeesés - miatt indított perekben jelent meg, melyekben a városbíró mint közvádló szerepelt. ${ }^{5}$ Joggal feltételezhetjük tehát, hogy már jóval 1614-es feltűnése előtt a város szolgálatába szegődhetett. Elismertségét az is jól példázza, hogy prókátortársai is, ellenfeleinek az ügyvédjei is többnyire a város elismert prókátorai közül kerültek ki: Bottalnősző Bessenyei Menyhárt, Gáltői Mihály, Széles Lukács, Lénárt István vagy Fodor Tamás. 1612-ben Barkai Ambrus nemes, a fejedelmi kancellária íródeákja, majd a gyulafehérvári hiteleshely levélkeresője is igénybe vette szolgálatait. ${ }^{6}$

Kolozsvár esetében rögtön az elején ki kell emelnünk Báthory Kristóf 1577. márciusi kiváltságlevelét, melyben a vajda engedélyezte, hogy - más közhitelű pecséttel rendelkező szabad királyi városok mintájára - Kolozsvár magisztrátusa is ügyvédvalló levelet állítson ki a várost egyházi, vagy világi bíróságok előtt képviselő prókátorok részére. ${ }^{7} \mathrm{~A}$ város prókátorainak a kinevezése a városi magisztrátus hatáskörébe tartozott. 1577-es és 1581-es adatok szerint a százférfiak tanácsa az ortálymondóknak - a tanács törvénykezési ügyekkel megbízott tagjainak $^{8}$ - adta feladatul ezeknek a megfogadását. ${ }^{9}$ Általában azonban a százférfiak kérésére és az általuk alkalmasnak ítélt személyekre tett javaslatok alapján a fóbíró és az esküdtek nevezték ki a legmegfelelőbbnek ítélt személyeket. ${ }^{10}$ Hivatali esküformulájuk nem maradt ránk, azonban Sárdi Miklós gyulafehérvári városi prókátor fennmaradt esküjének szövege jó párhuzamot kínál. Abban a prókátor vállalta, hogy mind a város által indított, mind a város ellen kezdeményezett perekben hűséggel szolgál, nem vállal fel olyan pereket, melyben a város mint közösség volt az alperes, és azt is megfogadta, hogy a város privilégiumainak tartalmát mások előtt fel nem fedi. Fizetségként megmunkálható nyílföldet és pénzt kívánt. ${ }^{11}$

4 GyJk 31, 35-36, 39.

5 GyJk 141, 143, 171, 233-234, 236, 281-282, 284.

6 GyJk 268; Gálfi Emőke: A Barkai család = „...éltünk mi sokáig 'két hazában'...” Tanulmányok a 90 éves Kiss András tiszteletére. Szerk. Dáné Veronka-Oвоrni Teréz-Sipos Gábor. Debreceni Egyetemi Kiadó, Debrecen, 2012.148-151.

7 Јакав Elek: Oklevéltár Kolozsvár történetébez. II-III. Bp., 1888. 101-103. (LIII. oklevél) (a továbbiakban JАКАв 1888a); Uő: Kolozsvár története. II. Bp., 1888. 240. (a továbbiakban JАKAв 1888b)

8 Erdélyi Magyar Szótörténeti Tár. X. Szerk. Szabó T. Attila et alii. Akadémiai-EME, Bp-Kvár, 2000. 52.

9 A Román Nemzeti Levéltárak Kolozs megyei Osztálya, Kolozsvár (a továbbiakban RNLtKol), Kolozsvár város levéltára (a továbbiakban KvLt), Tanácsülési/Közgyúlési Jegyzőkönyvek I/3.148v, 237. (a továbbiakban KvTanJk)

10 KvTanJk I/3. 226 $; \mathrm{I} / 4.3^{\mathrm{v}} ; \mathrm{I} / 5.3^{\mathrm{v}}, 5^{\mathrm{v}}, 31$.

11 Esküjében azonban azt is kikötötte, hogy, nemesi rangjára való tekintettel, a nemesség szabadságai ellen indított perekben a város érdekében nem lépik közre, mert „az féle causákban magamra nem illik támadnom." GyJk 17. Kolozsvár esetében azonban városi polgár hasonló kikötéssel nem élhetett, mivel, ha netán volt is nemesi rangja, annak előnyeit a város falain belül nem érvényesíthette. A kérdés egyes vetületeirôl lásd: PАKó László: Városi polgár-vármegyei nemes? Nemesek ingatlanszerzése Kolozsváron a fejedelemség korában $=$ A reneszánsz Kolozsvár. Szerk. Kovács András-Kovács Kiss Gyöngy. Kolozsvár Társaság, Kvár, 2008. 222-255. 
A várost szolgáló ügyvédek számáról a rendelkezésünkre álló adatok nem adnak pontos eligazítást. Úgy véljük, hogy egy, esetenként két prókátort alkalmaztak állandó jelleggel, s csak szükség esetén vette újabbak szolgálatait is igénybe a tanács. ${ }^{12}$

A városi dolgaiban eljáró prókátorok között meg kell különböztetnünk a teljes évre alkalmazott, többnyire csak a város belső ügyeiben tevékenykedő, valamint az esetenként felfogadott, a fejedelmi tábla, a vármegyék vagy más törvényhatóságok bírósága előtt szereplő perbeli képviselők között. ${ }^{13}$ Mivel a város törvénykezési szokásainak, törvényeinek és statútumainak, valamint a különféle peres ügyek részleteinek a beható megismeréséhez idő kellett, a teljes évre szegődtetett prókátorok legtöbbje több éven keresztül szolgálta a várost. Az idegen törvényhatóságok bíróságai elôtt hosszasan húzódó városi perek esetén is gyakran fordult elő, hogy ugyanazt a személyt hosszabb időn keresztül foglalkoztatták.

A fő́bíró és az esküdtek feladata volt, hogy - a centumvirek jóváhagyása mellett - kiegyezzenek a prókátorokkal bérükról. ${ }^{14}$ Gyér forrásaink azt valószínúsítik, hogy a teljes éven keresztül foglalkoztatott prókátoroknak az 1580-as évek elején évi 10 forintos fizetése volt, ezt az 1590-es évekre a magisztrátus megduplázta. Mentesültek a városi adó, illetve szolgáltatások fizetésétól, a többi városi tisztségviselőhöz hasonlóan a város védelme alatt álltak, ${ }^{15}$ és idônként még bizonyos anyagi javakat is kaptak. ${ }^{16}$ Emellett a magisztrátus megtérítette a város pereire fordított kiadásaikat is. ${ }^{17}$ Velük szemben az időszakosan megfogadott ügyvédek mindig az aktuális munkáik után kapták fizetségüket. ${ }^{18} \mathrm{~A}$ jegyzők évi 100 forintos bérének viszonylatában éves járandóságuk kevésnek túnhet, mivel azonban mindannyian magánszemélyek ügyeiben is tevékenykedtek még, a városi szolgálat, anyagi hozadéka mellett, bizonyára jelentős szakmai és tekintélybeli előnyökkel járhatott. A város pereiben is tevékenykedő prókátorok joggal számíthattak előkelőbb és szélesebb körü klientúrára, mint kizárólag magánszemélyek szolgálatában álló társaik.

A fő́bíró nemcsak megfogadta őket, hanem irányította és felügyelte is a tevékenységüket. Felvilágosította őket a város pereinek a részleteirôl, felhívta figyelmüket a város legfontosabb privilégiumaira, tanácsokat adott arról, hogy szükség esetén kihez forduljanak jogi tanácsért, ${ }^{19}$ tanúvallomások bevételére vagy bünözők letartóztatásának végrehajtására küldte ki

12 A legtöbb adat egy prókátorról beszél (KvTanJk I/3.148v , 226v , 237; I/4.3.), 1581-ben azonban „az ket feo procator" dolgáról határoztak a centumvirek. KvTanJk I/3. 238.

13 1588. január: "Az procurator vraim walaztasat, mind it a varosba, s mind tablara, warmegiekre eo kegjelmek varosul hattak biro vramra tanacchawal egjetembe.” KvTanJk I/5. 31. 1580: „Miert penig hog $\ddot{y}$ az warmegien is sok perink essjk, az varas procatora penigh egjedwl elegtelen annj dologra..." KvTanJk I/3.226v. 1585. január: „... minemeo nehez pereÿ volnanak az varosnak, feokeppen az hatarok feleól, es procuratorok kellenenek azoknak gondwisselessere ..." KvTanJk I/5.3".

14 KvTanJk I/3. 164.

15 KvTanJk I/3.184v' 185, 237, 251, 252; RNLtKol, KvLt, Számadáskönyvek 5/I. 105; 5/XXI. 65; 6/V. 9. (a továbbiakban KvSzám)

16 1592-ben a városi prókátor például 25 forint értékben kapott gránát posztót a sáfárpolgártól. KvSzám 5/XIV.325.

17 A sáfárpolgárok, a városi közügyigazgatók és az adószedők 1580-90-es évekből való számadásai gyakran sorolnak a prókátoroknak kifizetett pénzösszegeket.

18 KvTanJk I/5. 6v; KvSzám 4/XXI. 22.

19 1573. július 1-jén a százférfiak a következő utasítást adták a fóbírónak: „Biro vram az varos procuratorat [...] hjwatna ide es az mjnemw perek az varost nezik azokrwl zolna vele, es az mj igassaga, 
őket, ${ }^{20}$ folyamatosan figyelmeztette vállalt kötelességeik betartására, ${ }^{21}$ és, ha kellett, az ügyintézés meggyorsítására szólította őket. ${ }^{22}$ Mindez a százférfiak tanácsának felügyelete, nem ritkán erélyes beavatkozása mellett történt. ${ }^{23}$

Ami a városi prókátorok által képviselt ügyeket illeti elsőként említjük a fejedelmi tábla előtt rendszerint a városnak a kincstár vagy a szomszédos településeken birtokos nemesek által elfoglalt birtokai, vagy e jószágok feletti másfajta ellentétek miatt indult pereit. De fogadott prókátorok által lépett fel a város 1569-ben ebesfalvi Apafi Gergely, majd 1584-ben annak fia, Miklós ellen is, akik káposztásszentmártoni birtokukon jogtalanul vámfizetésre kényszerítették a kolozsvári kereskedőket. ${ }^{24}$ Vármegyék vagy más törvényhatóságok bíróságai előtt is megjelentek Kolozsvár prókátorai a polgárok olyan ügyeiben, melyeket nem a kolozsvári bíróság tárgyalt. ${ }^{25} \mathrm{~A}$ város belső ügyeiben illetékes prókátorokat a centumvirátus 1579-ben eskü által kötelezte arra, hogy minden tudomásukra jutott gyilkosság, paráznaság, házasságtörés vagy rablás esetén azonnal eljárjanak. ${ }^{26}$

A város törvénykezési jegyzőkönyveinek adatai bizonyítják, hogy ezek valóban számos büntetőjogi ügyben indítottak eljárást. Vádlottjaik között gyilkosok, paráznák, házasságtörők, kerítők, boszorkányok, gyújtogatók, tolvajok vagy adósságaikat nem törlesztő személyek voltak. Felléptek olyanok ellen is, akik sértő szavakkal illették a város elöljáróit, akik kifecsegték a városi magisztrátus titkait, és akik elsikkasztották a város vagy egyes városi intézményeknek a javait. Bíróság elé állítottak bűncselekmény elkövetésével gyanúsított prókátort, városi darabontokat és a város falvainak visszaélésekkel gyanúsított ispánjait is.

Mindezek mellett e prókátorokra hárult az örökös nélkül elhunyt városiak javainak, illetve a végrendeletileg a városra testált javaknak a megszerzése és adminisztrálása is. ${ }^{27}$ Báthory István fejedelem 1575-ös kiváltságlevelében ugyanis engedélyezte, hogy az utód nélküli kolozsváriak vagyona ne a kincstárra, hanem a városra szálljon saját épületei és a városfalak karbantartására. ${ }^{28} \mathrm{E}$ megszerzett kiváltság érvényesítése azonban gyakran ütközött a kincstár

priuilegiuma vagion az varosnak, elejbe adna, hogj ertene mikeppen kellien az varos zabadsagat oltalmaznj [...] hjwassak elj, zollianak vele, vegezzenek mindent elj, hogi ne maradjon azkorra, mjkor chiak az teorwenre eleh kellien allanj. Ez mellet, ha zwokseg, az iteleo mestereket is thanachoznj." KvTanJk I/3. 88.

20 KvSzám 3/V. 11, 16, 18; 5/XIV. 157; RNLtKol, KvLt, Törvénykezési jegyzőkönyvek, II/8. 86. (a továbbiakban KvTJk)

21 „...fenjtekbe tarchja, hogj tjztekbe hÿwen el jarjanak amj az varos dolgait illeẗ̈.” KvTanJk I/3. 207.

22 „... zorgalmaztassa az procatort hogj az warmegien vjgjek zorgalmatosson vegbe az dolgot.” KvTanJk I/3. $226^{\mathrm{v}}$.

23 1571. január elején például megtiltották, hogy a város prókátorai idegen ember várossal szembeni ügyében eljárjanak. KvTanJk I/3. 30.

24 Kiss András: Privilegii şi acte privind istoria oraşului Cluj (1203-1592). Kézirat (a továbbiakban Kiss: Privilegii). A kéziratot Kiss András jóvoltából tanulmányozhattam.

25 Egy városi prókátor Magyarlónán[?], egy másik Bonchidán intézkedett városiak ügyeiben. KvTJk II/7. 5-9; KvSzám 3/V. 11, 16, 17, 18, 42, 43; 6/VI. 15.

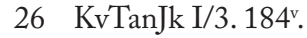

27 1579: „.. ha hul penig valamÿ magwa zakat jozagh essÿk, tehat arra is zorgalmatos gondot wjsseljenek.” KvTanJk I/3.184v . 1580-ban például a százférfiak arra buzdították a városi prókátorokat, hogy minél előbb vegyék kezelésbe azt az 50 forintot, melyet Kappa Antal felesége végrendeletében a városra hagyott, de közben az utódok kezelésébe került. KvTanJk I/3. 208.

28 ЈАКАв 1888a. 97-98. (L. okl.) 
vagy a javakra igényt formáló örökösök ellenkezésébe, az ilyen ügyek megoldása pedig kezdetben szintén a városi prókátorok hatáskörébe tartozott. ${ }^{29}$

Igyártó György 1586-os számadásai azt mutatják, hogy a városi prókátorok mindkét szerepkörben igyekeztek helytállni. ${ }^{30} \mathrm{~A}$ városi közügyigazgatók intézményének a megjelenése az 1580-as évek második felétől azonban fokozatosan visszaszorította a városi prókátorok hatásköreit. Miután ugyanis a centumvirek 1587-ben pontosan körülhatárolták a direktorok teendőit, a közbűntettek üldözésének hivatali kezdeményezése, akárcsak az utód nélkül elhunyt városiak öröksége megszerzésének a joga ez utóbbiak kezébe ment át. ${ }^{31}$ Így az 1590-es évektől a város fogadott prókátorainak közremúködését leginkább az idegen törvényhatóságok előtt folyó perekben igényelte.

\section{PRÓKÁTOROK MAGÁNSZEMÉLYEK SZOLGÁLATÁBAN}

Előbb már említettük, hogy minden bíróság elé idézett személy jogosult volt érdekeinek perbeli képviseletére prókátort fogadni. Habár Báthory Kristóf 1577. márciusi kiváltságlevelének értelmében magánszemélyek csupán hiteleshelyek előtt vallhattak prókátort, a városvezetés határozott fellépését követően a vajda engedélyezte, hogy a városi bírák és esküdtek Kolozsvár minden lakója számára az ország minden világi vagy egyházi bírósága előtt érvényes ügyvédvalló levelet állíthassanak ki. ${ }^{32}$ Egy 1582-es nótáriusi instrukció szerint prókátort a bíró jelenlétében lehetett vallani, a vallomás írásba foglalásáért pedig két forint járt a jegyzőnek. ${ }^{33}$ A fejedelmi tábla ítélőmestereinek a példájára hivatkozva azonban a centumvirek ellenezték, hogy prókátorvallásért a főbíró is fizetséget kérhessen. ${ }^{34}$

A magánszemélyek nevében fellépő prókátorok tevékenységének szabályozása és felügyelete is a városbírák és az esküdtek hatáskörébe tartozott, a százférfiak tanácsa csupán felülbírálta határozataikat, illetve ellenőrizte azok gyakorlati alkalmazásának módját. ${ }^{35} \mathrm{~A}$ prókátorokkal foglalkozó városi statútumok nagy száma azt sugallja, hogy munkájukkal kapcsolatban számos probléma merült fel. A főként perrendtartási intézkedéseket tartalmazó 1577-es, majd az azt kibővítő 1588-as statútumok hangot is adtak a legégetőbb gondoknak: a keresetek előadása és a feleletek beadása során a jogi jártasságukat, elméjüket fitogtató ügyvédek anyagi haszon reményében késleltették a perek végleges megoldását, ami a peres felek anyagi kimerüléséhez vezetett. ${ }^{36}$ Mindezek megelőzése érdekében a szabályzatok eskü által kötelezték őket, hogy ügyfeleikkel szemben tanúsítsanak őszinteséget és hűséget, pereikben igazsá-

29 РАко́ László: A városi közügyigazgatók (direktorok) Kolozsvár 16. század végi birósági gyakorlatában. Erdélyi Múzeum LXXIV(2012). 3. sz. 92 (kiemelten a 23. jegyz.). (a továbbiakban PAkó 2012)

30 РАко́ 2011. 97.

31 РАКо́ 2012.97-98.

32 Јакав 1888a. 105-108 (LV. okl.); Јакав 1888b. 241.

33 KvTJk II/1. (Liber civitatis) 187.

$34 \mathrm{KvTanJk} \mathrm{I/3.6,8v.}$

35 KvTanJk I/3. 18, 147, 164v; I/5. 89, 243.

36 Corpus statutorum Hungariae municipalium. A magyar törvényhatóságok jogszabályainak gyújteménye. I. Szerk. Kolozsvári Sándor-Óvári Kelemen. MTA, Bp., 1885. 189-190, 229. (a továbbiakban CSHM); ЈакАв 1888b. 243. 
gosan, szorgalommal és körültekintően járjanak el, ne pártoljanak át az ellenfél oldalára, és hamis tényállású perben szánt szándékkal ne vállaljanak szerepet. Kikötötték továbbá, hogy a saját szakmai mulasztásból - bíróság előtti megjelenésnek, feleletek beadásának, perakta-másolatok kikérésének vagy perbeli lépések jegyzőkönyvbe vetetésének az elmulasztása - ügyfeleiknek okozott károkat ők maguk térítsék meg. ${ }^{37}$ Emellett túlzó anyagi követeléseik megfékezése érdekében folyamatosan foglalkoztak honoráriumuk kérdésével is. ${ }^{38} \mathrm{~A}$ prókátorok dijszabásainak a problémáját az 1577-es perrendtartási statútum szabályozta részletesen, melynek előírásait kisebb változtatásokkal az 1588 -as is átvette. ${ }^{39}$ Határozat írta elő azt is, hogy ha a peres felek még a per folyamán kiegyeztek, akkor az ügyvéd csak az addig végzett munkája után kaphatott fizetést, melynek összegét szükség esetén a főbíró állapította meg. ${ }^{40}$ Források hiányában e határozatok gyakorlati alkalmazásának mértéke nehezen mérhető le, Igyártó György alább ismertetésre kerülő prókátori tevékenysége azonban azt sugallja, hogy volt példa visszaélések elkövetésére is.

Néhány adat arról is megőrződött, hogy a prókátorok és ügyfeleik milyen furfangos megoldásokat találtak anyagi érdekeik egyeztetésére. Leggyakrabban a megrendelők a perek sikeréhez kötötték az ügyvédek munkájának honorálását. 1585-ben Henter Benedek 15 forintért vállalta el Nyírő István képviseletét, ebből előlegben csak 2 forintot kapott meg, a maradék összegre pedig csak siker esetén számíthatott. ${ }^{41}$ Szemléletes Ötvös Orbán 1586-os esete is, aki úgy egyezett meg Igyártó Györggyel, hogy prókátora a kialkudott 25 forintos bérét csak a per folyamán visszaszerzett összegből kaphatja meg. Ötvös kikötése akkor érthető meg igazán, ha tudjuk, hogy ő maga is prókátorkodott. ${ }^{42}$ Volt olyan eset is, amikor a megrendelő fizetség gyanánt termőföldjének használati jogát engedte át bizonyos időre ügyvédjének. ${ }^{43}$

Mivel mindnyájuk szakmai pályafutását jogi ismereteik és gyakorlatuk által megalapozott hírnevük, elismertségük vitte előre, mindig hevesen felléptek az ellen, aki megkérdőjelezte ezeket. 1573-ban egy bizonyos Tamás deák bíróság elé idézte azt a férfit, aki kocsmai nyilvá-

37 KvTanJk I/3. 8v ; CSHM 189-190, 229-231; ЈакАв 1888b. 243-244.

38 1569-ben például 5 dénárban maximálták a bíróság elé benyújtott kérvények árát. JАКАB 1888b. 134. 1570-ben elhatározták, hogy a 10 forint alatti perekben egy beállás ára nem lehet egy garasnál, azaz 5 dénárnál magasabb, a 10 forint fölötti perekben pedig az ügyféllel kellett egyezségre jutniuk. KvTanJk I/3. $8^{\mathrm{v}}$.

39 Adóssági ügyekben az 50 forint értékű vagy kevéssel afölötti perekben a prókátor az összeg tizedét kapta meg, a 100 forint feletti ügyek esetén 10 forintot, a 200-500 forintos ügyekben 20 forintot, az 500 forint feletti ügyek esetében pedig az összeg huszad részét. Becsület és hatalmaskodási ügyekben, ahol holtdíj fizetése forgott fenn, 10 forintot, ahol élődíj vagy nyelvváltság - mely büntetésnek csak a harmadát kapta meg a felperes - ott a felperest megilletô résznek csak negyedére volt jogosult az ügyvéd. Az 1588-as rendtartás a fentiekben csak apróbb változtatásokat eszközölt. CSHM 191, 230; Јакав 1888b. 243-244.

40 KvTanJk I/5.39v.

41 KvTJk II/7. 401, 401a-d, 407, 528, 528a.

42 KvTJk. 558. Hasonló esettel Gyulafehérváron is találkozunk. Sárdi Miklós prókátor Mészáros Istvánnal való megegyezése értelmében magára vállalta a per költségeit, Mészáros pedig vállalta, hogy a jószágok visszaszerzése után pénzben vagy igazbecsû́ útján a visszakapott javakból törleszti ügyvédje költségeit. ErdKáptJk 577. sz.

$43 \mathrm{KvTJk} \mathrm{II/8.225.}$ 
nosság előtt gyenge prókátornak, cigánynak és más deáknál képzetlenebbnek nevezte őt. ${ }^{44} \mathrm{~A}$ tapasztaltabb ügyvédek pedig egyenesen elálltak az olyan kétes tényállású vagy bizonytalan végkifejletű ügyektől, melyek beszennyezhették hírnevüket. 1583-ban például Baki Pál kérte Ötvös Orbánt, hogy Balázsfi Gergelytől szerezzen vissza bizonyos letétbe helyezett és tőle eltulajdonított javakat. Ötvös azonban visszamondta a felkérést, mert megítélése szerint a háborús időkben történt dolgok miatt indult perek végkifejlete legtöbbször bizonytalanul alakult. $^{45}$

A prókátorok irányába támasztott városi követelmények között kiemelt helyet foglalt el a városi bírósági gyakorlat és perrendtartás részleteinek az alapos ismerete. 1585-ben a magisztrátus megtiltotta az idegen prókátoroknak a városi bíróság előtti megjelenését addig, amíg az újonnan hozott perrendtartási szabályok gyökeret nem vernek a városi bírósági gyakorlatban. ${ }^{46}$

\section{PRÓKÁTORKARRIEREK KOLOZSVÁRON}

Eddig csupán általánosságban szóltunk a kolozsvári prókátorság intézményéről, a következőkben viszont néhány olyan személy szakmai pályafutását vesszük számba, melyek 16. század végi kolozsvári prókátorkarrierek egy-egy tipikus példáját szemléltetik.

Igyártó György Kolozsvár 16. század végi bírósági gyakorlatának meghatározó és egyben legvitatottabb prókátora volt. Csak sejtjük, hogy jómódú városi polgárcsalád tagja lehetett, akinek kolozsvári magánszemélyek ügyvédjeként teljesített tevékenysége 1576-tól adatolható. Személyére először 1582-ben akkor terelődött a figyelem, amikor farsangi álruha viselésének vádjával indított pere során házasságtöréssel, titkos kapcsolatából született csecsemőjének a meggyilkolásával és első feleségének a szándékos megmérgezésével vádolták. A vádakat úgy hárította, hogy azok felívelő prókátori pályájára nem lettek hatással. Magánpraxisa mellett 1584-től a város fogadott prókátoraként említik a források, ebben a beosztásában a közerkölcsöt, a közbiztonságot és a városlakók vagyonát veszélyeztető bűncselekmények elkövetőit idézte bíróság elé. Fényesnek ígérkező ügyvédi karrierje azonban hirtelen megtorpant. 1586ban a centumvirátus, noha méltányolta korábbi eredményeit, beszűkítette városi prókátori hatásköreit, és minden perbeli lépését a fóbíró engedélyéhez kötötte. Egy 1586 áprilisában kezdődő persorozat azt sugallja, hogy az intézkedésre azért került sor, mert Igyártónak számos törvénytelen ügyvédi praktikájára derült fény: több perben egyszerre vállalta mindkét peres fél képviseletét; titkos egyezségre lépett megbízói ellenfeleivel vagy azok ügyvédjeivel; per közben pártolt át ellenfele oldalára vagy vesztegette meg azok ügyvédjeit. Valószínű e vádak miatt mentették fel városi ügyvédi beosztásából, ezután ugyanis semmilyen adat nem szól ezirányú prókátori tevékenységéről. 1592-ben özvegyét említik forrásaink, aki elhunyt férje után maradt sok adóssága miatt kérte a tanács segítségét.

Szakmai pályafutása tekintetében ügyvédi felkészültségéről nincsenek adataink, feltehetően a családi környezet hatott rá, majd a gyakorlat során tanult bele a mesterségbe. Városi pol-

44 KvTJk II/6. 143-144.

$45 \mathrm{KvTJk} \mathrm{II/7.} 197$.

46 KvTanjk I/5. 5v. 
gárok szolgálatában kezdte karrierjét, megbízóinak több mint fele a várost vezető elithez tartozott. Közel egy évtizedes magánügyvédkedés után lett a város fogadott prókátora, s e beosztásban az ő nevéhez köthető a hivatali perindítás szokásának a meghonosítása a város bírósági gyakorlatában. Pályafutása ugyanakkor azért is tanulságos, mert nemcsak prókátori tevékenysége révén hozott újítást a kolozsvári igazságszolgáltatási gyakorlatba, hanem bukásával is. Kétszínű tettei ugyanis arra mutattak rá, hogy egy, a városi közvádló szerepét is betöltő, de ugyanakkor magánszemélyek pereit is felvállaló prókátor kezében összpontosuló hatalom könnyen felhasználható személyes előnyök szerzésére. Ez a felismerés vezethetett oda, hogy a százférfiak 1587 márciusában a hivatalból indítandó perek kezdeményezésének jogát kizárólag közvádlók, a nemrég létrehozott városi közügyigazgatók kezébe adták. Ettől kezdve magánszemélyeket is képviselő prókátorokat nem találunk ilyen szerepben. ${ }^{47}$

Igyártót a városi prókátori tisztségében Kalmár János követte. 1588-as adatok szerint a sáfárpolgár negyedévenként utalta fizetését a város érdekében indított perekhez kapcsolódó teendőiért. ${ }^{48} \mathrm{E}$ tevékenységét azonban rövid ideig folytathatta, 1589 szeptemberében ugyanis már néhaiként említik. ${ }^{49}$ Származását tekintve ő is előkelő városi család sarja, apja az 15501560-as években esküdtpolgári és királybírói tisztségeket is betöltő kolozsvári polgár, Kalmár László volt. ${ }^{50} 1567$ januárjában apjuk már halott, árvái közül az akkor serdülőkorú János és Péter nevű öccse függetleníti magát Nyírő Kálmán és Vicei János gyámsága alól. ${ }^{51}$ Valószínű tehát, hogy János az 1550-es évek első felében a család elsőszülöttjeként látta meg a napvilágot. 1569-ben már a centumvirátus tagjai között találjuk, 1572-1586 között többször töltött be esküdtpolgári, vonásigazgatói és számvevői tisztségeket is, 1572-1573 folyamán esküdtpolgárként tanúkihallgatásokon vett részt. ${ }^{52} \mathrm{Ez}$ idő tájban keletkezett adatok árulkodnak magánszemélyek ügyvédjeként teljesített korábbi szolgálatairól is. ${ }^{53}$ Jogi kérdésekben való jártasságát, akárcsak Igyártó esetében, csak feltételezzük, hogy családi környezetben szerezhette. Bizonyos viszont, hogy prókátorként vált a városi magisztrátus prominens tagjává. Feleségét, Budai Tamás Margit nevű lányát, a város szintén előkelő családjából választotta. ${ }^{54}$ Apósa révén (akinek első felesége Pécsi Erzsébet volt, a második Herceg Antal lánya) ${ }^{55}$ rokonságba került a Nyírő családdal - közülük Kálmán futotta be a leglátványosabb városi karriert ${ }^{56}$ - to-

47 Személyéről és tevékenységéről bővebben lásd Pakó 2011. 93-103.

48 KvSzám 4/III. 4, 8, 19.

49 KvTJk II/1. 227-228.

50 KvTJk II/1. 43; KvTanJk I/1. a borító belsején; I/2. 131'; Kiss: Privilegii 451, 461, 471, 473. sz.; Magyar Nemzeti Levéltár Országos Levéltára (a továbbiakban MOL), R 314, Városi iratgyújtemény, 10. doboz, Vegyes iratok, 2a csomag, 14r.

51 Az apa halálát követően hosszú persorozat indult a hátramaradt vagyon elosztása felett részint az utódok és a gyámok, részint az utódok és Kalmár második felesége, részint pedig a gyámok és Kalmár özvegye között. KvTJk II/1. 65-183, passim.

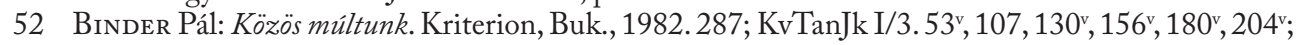
I/5. 20v; KvTJk II/6; II/7. 552; KvSzám 3/II. 1a; 3/XXIII. 1.

53 KvTJk II/6. 108a-b.

54 KvTJk II/1. 227-228.

55 Uo. 191-195.

56 Felesége, Anna, Pulacher István testvére volt. 1566-1582 között centumvir, esküdtpolgár, királybíró, fóbíró és számvevő is volt, mígnem a szolgálóival fenntartott parázna kapcsolatai miatt menesztették a magisztrátusból. KvTJk II/1. 55; KvTanJk I/2. 131; I/3. 2, 95v, 107v, 139v; Boszorkányok, 
vábbá Herceg Gáspárral és Pulacher Istvánnal, akik apósával együtt meghatározó befolyásra tettek szert a városi szenátusban. ${ }^{57}$ Végül testvére, Kalmár Orsolya házassága révén a családba került Bornemissza Gergely ötvös is, aki szintén jelentős városi karriert futott be ${ }^{58}$ Kalmár Jánosnak Budai Tamás lányával kötött házassága tehát csak tovább konszolidálta a városi elit soraiban elfoglalt helyét, ${ }^{59} 1589$ körüli magtalan halála azonban véget vetett ígéretes városi prókátori karrierjének.

Más pályát járt be az a szintén kolozsvári származású Horvát Imre, akinek 1595-1598 között rendszeresen fizetett a város peres ügyeiben való közbenjárásáért. ${ }^{60} 1577-1590$ között a fejedelmi nagyobb kancellária íródeákjaként tevékenykedett, 1585-ben nemesnek titulálják. ${ }^{61} 1590$-ben már biztosan nős, felesége, Cementes Katalin ${ }^{62}$ annak a Cementes János ötvös mesternek volt a lánya, aki 1560-tól kolozsvári centumvirként, 1574-től esküdt polgárként,

kuruzslók, szalmakoszorús paráznák. Vál, bev, jegyz. Kiss András. Kriterion, Kvár, 2004. 35-36, 8096; PAкó László: Hatalmi konfliktus vagy testületi összefogás? A kolozsvári százférfiak tanácsa és a városi igazságszolgáltatás a 16. század második felében. Erdélyi Múzeum LXXII(2010). 3-4. sz. 83. (a továbbiakban PAKó 2010)

57 A Herceg-Budai-Pulacher rokonság kapcsolatairól és városvezetésben betöltött szerepéről lásd Flóra Agnes: Prestige at Work. Goldsmiths of Cluj/Kolozsvar in the Sixteenth and Seventeenth Centuries. Saarbrücken 2009.51-52. (a továbbiakban FlóRA 2009) Hatásuk a város igazságszolgáltatásra is szembetűnő: a rokonságnak legalább egy tagja a 16. század utolsó két évtizedében - egyetlen év kivételével - folyamatosan jelen volt a városi bíróság első- vagy másodfokú ítélkezési fórumainak munkájában. Három évben a fóbíró, a királybíró, és egy, de akár két esküdtpolgár is közülük került ki. PАкó László: Valoarea viętii umane în Clujul ultimelor două decenii ale secolului al XVI-lea. Infracțiunile de omucidere. Doktori értekezés, Babeş-Bolyai Tudományegyetem, Kvár. 4142. További adatok: KvTJk II/1.191-195; A kolozsvári osztóbirói intézmény és a kibocsátott osztálylevelek. S.a.r., bev, jegyz. Kovács Kiss Gyöngy. Korunk-Komp-Press, Kvár, 2012.44. (a továbbiakban A kolozsvári osztóbirói intézmény)

58 1563-ban belépett az ötvös céhbe, 1573-ban céhmester lett és beválasztották a százférfiak tanácsába is. Volt vonásigazgató, adószedő és számvevő is, többször került be az esküdtpolgárok soraiba.

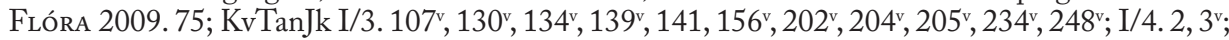
I/5. 1, 11v, 29, 78, 86v, 104v $, 145^{v}, 154^{v}, 165 ;$ KvSzám 3/X. 8; 3/XXIII. 1; 3/XXIX. 1; 4/XVI. 2a; 7/IV. 1.1585-ben a fejedelem aranykamarásaként (auricamerarius) említik. MOL, Erdélyi Országos Kormányhatósági Levéltárak, A Kolozsmonostori Konvent Országos Levéltára, F 15 Protocolla, libri regii et stylionaria, IX, 54 $-55^{\mathrm{r}}$. (a továbbiakban KmProt) (Az adatra Bogdándi Zsolt hívta fel a figyelmem.)

59 Az asszony férje halála után is előkelő körökben maradt: 1606 körül a Bácsi család János nevủ tagjának lett a felesége, akinek anyja, Igyártó Sára, révén Igyártó Ötvös Mihály aranykamarás és városi elöljáró, valamint a Vicei család tagjai is a rokonságába kerültek. A kolozsvári osztóbirói intézmény 101-102.

60 KvSzám 6/XIV.37, 53; 6/XVI. 13, 26; 6/XVII. 147; 6/XXIX. 65-66, 69, 81; 7/XIV. 3, 7, 55; 7/XVI, 96.

61 TrócsánYi Zsolt: Erdély központi kormányzata. 1540-1690.Akadémiai, Bp., 1980.191; ErdKáptJkv 403, 460, 486, 687. sz.; Az erdélyi fejedelmek Királyi Könyvei. I. 1569-1602. Báthory Kristóf Királyi Könyve (1580-1581). Mut, jegyz, reg. Fejér Tamás-Rácz Etelka-Szász Anikó. EME, Kvár, 2003 (Erdélyi Történelmi Adatok VII. 2). 52, 64, 82, 97, 182. sz.; Báthory Zsigmond Királyi Könyvei (1582-1602).Mut, jegyz, reg. Fejér Tamás-Rácz Etelka-SzÁsz Anikó. EME, Kvár, 2005 (Erdélyi Történelmi Adatok VII. 3). 447, 1186. sz. (a továbbiakban ErdKirKv); KmProt IX. 41-42vi X. $10^{\mathrm{r}-\mathrm{v}}$.

$62 \operatorname{KmProt} X \cdot 10^{r-v}$. 
előbb a kolozsvári, majd 1571-től a Szebenbe áthelyezett pénzverde aranyelválasztójaként szerzett magának érdemeket. ${ }^{63}$ Horvát tehát kancelláriai íródeákként alapozta meg későbbi karrierjét, ott szerezhette meg a gyakorlati jogban való jártasságát, melynek birtokában prókátorsággal is foglalkozott. E tevékenysége társadalmi előhaladását is segítette, nemesi rangot szerzett és előkelő családból nősült. Egyelőre nincs adatunk olyan perről, melyben városiak magánügyeit képviselte volna, ha azonban a forrásokban megjelenő Imre deákot helyesen azonosítjuk vele, akkor az erdélyi unitárius szuperintendens ítélőszéke előtt is ügyvédkedhetett. ${ }^{64}$ Mivel védencei között a kolozsvári Vicei család egyik tagja mellett sárvári, azaz Doboka vármegyei személyeket is találunk, továbbá mivelhogy Bélteki Sámuel és Kolozsvári Márton deák ${ }^{65}$ voltak prókátortársai, illetve ellenfelei azt mutatják, hogy hírneve jócskán túllépte a városi kereteket.

Trauzner Lukácsot szintén a város prókátorai között tarthatjuk számon. A szakirodalomból tudjuk, hogy kolozsvári szász polgárcsalád sarja lehetett, aki itáliai tanulmányainak befejeztével, 1576-ban elvállalta a kolozsvári jegyzői hivatalt. Dávid Ferenc lányát vette feleségül, később a vallásújításért perbe fogott apósa védelmében lépett fel.1582-ben felhagyott a városi jegyzőséggel, és nagy valószínűséggel ügyvédkedésre adta a fejét. Habár ez idő tájt kifejtett prókátori tevékenysége alig dokumentált, a kutatás azt valószínűsíti, hogy addigra kialakult egy olyan vármegyei klientúrája, melynek támogatására támaszkodva belevághatott a prókátorkodásba. Tény, hogy a Gerendi család érdekében kifejtett szolgálatai jutalmául 1588ban birtokadományban részesült, és a Torda vármegyei nemesség sorába léphetett. 1590-ben a fejedelem utódaival együtt megnemesítette, 1593-tól pedig az országos adóigazgatásban jutott szerephez. 1600-ban ítélőmesterként említik, 1607-től pedig elnyerte a fejedelmi tábla elnöki tisztségét, melyet következő évben bekövetkezett haláláig töltött be. ${ }^{66}$

Noha az eddigi kutatások nem részletezték, a városi források alapján újabb adatokkal bővíthetjük kolozsvári tevékenységéről szóló ismereteinket. Azt tudtuk, hogy 1576-1582 között a város jegyzője volt, 1578-ban pedig bekerült a százférfiak tanácsába is. A jegyzőség felhagyásának körülményei azonban egyelőre homályosak. A megfejtéshez Kolozsvár város tanácsülési jegyzőkönyvei nyújthatnak újabb fogódzót. Trauzner ugyanis az 1582-es év első negyedére megkapta még jegyzői szolgálatainak kántoros (negyedévi) bérét, ${ }^{67}$ az év áprilismájusában azonban a százférfiak tanácsának több üléséről is hiányzott. Az akkor született

63 Bunta Magdolna: Kolozsvári ötvösök a XVI-XVIII. században. Magyar Nemzeti Múzeum, Bp., 2001 (Bibliotheca Humanitatis Historica XVII). 185; FLóra 2009. 23, 39-40.

64 Erdélyi Unitárius Egyház Gyújtólevéltára, Kvár, Parciális (és Főtanácsi) Jegyzőkönyv I. 1587-1606. 101,106, 116,139-141. (a továbbiakban UnitJk)

65 Béltekiről lásd alább; Kolozsvári Márton deák kolozsvári centumvir, Kolozs vármegyei jegyző, kolozsmonostori requisitor, fejedelmi táblai ülnök és ítélőmester is volt, kiemelkedő jogi ismeretei és jártasságai tehát megkérdőjelezhetetlenek. Bogdándi Zsolt: A kolozsmonostori konvent a fejedelemség korában. EME, Kvár, 2012 (Erdélyi Tudományos Füzetek 274). 74-76.

66 BaLÁzs Mihály: Trauzner Lukács megtérése = Uő: Felekezetiség és fikció. Tanulmányok 16-17. századi irodalmunkról. Balassi, Bp., 2006 (Régi Magyar Könyvtár. Tanulmányok 8).109-118; DÁné Veronka: A Trauznerek a fejedelemség korában = Emlékkönyv Kiss András nyolcvanadik születésnapjára. Szerk. Pál-Antal Sándor-Sipos Gábor-W. Kovács András-Wolf Rudolf. EME, Kvár, 2003. 81-89.

67 KvSzám 3/V. 56. 
közgyúlési határozatok azt sejtetik, hogy a jegyző a városon kívül kényszerült tartózkodni. ${ }^{68}$ Ez pedig nagy valószínúséggel a Báthory István által 1582 tavaszán a radikális antitrinitarizmus több kolozsvári képviselője, nevezetesen Trauzner Lukács, Bogáti Fazekas Miklós és Jacobinus Bernát ellen elrendelt vizsgálat lehetett. ${ }^{69}$ Egyelőre kérdéses, hogy Trauznert a vizsgálat vezetői - Kovacsóczy kancellár és a fejedelmi tanács tagjai - rendelték-e magukhoz, vagy Bogátihoz hasonlóan az esetleges büntetés elől menekülve hagyta el a várost, a tanács viszont az ügy elhúzódása és bizonytalan kimenetele miatt, egy hónapi várakozás után, új jegyző megválasztásáról döntött. Tette ezt annak ellenére, hogy elismeréssel nyilatkozott Trauzner addigi tevékenységéről, és biztosította őt további támogatásáról. ${ }^{70} \mathrm{E}$ lépésük - amellett, hogy bizonyítja a jegyzőnek a városigazgatásban és bíráskodásban betöltött pótolhatatlan szerepét - Trauzner kolozsvári jegyzői tisztségéből való távozásának okairól is beszélni látszik. Ha a korábbi adatok alapján úgy túnhetett, hogy Trauzner önszántából vált meg kolozsvári jegyzői hivatalától - minthogy addigra kialakulhatott egy igen előkelő ügyvédi ügyfélköre -, adataink azt sugallják, hogy valójában a városi tanács döntött mellőzéséről. Továbbá tekintve, hogy 1582 előtti prókátori tevékenysége egyelőre csupán Dávid Ferenc védelmében való 1579-es fellépése által adatolt, elképzelhető, hogy a városi jegyzői tisztségből való kényszerű távozása késztette a prókátorkodásra és ügyvédi karrierjének kibontakoztatására, s nem addigra kiforrott klientúrája miatt tért át a prókátorságra.

A jegyzői tisztségből való távozása ellenére jó kapcsolatban maradt a városi magisztrátussal. 1582 decemberében már a városi vízfolyások ellenőrzésére választott nyolc centumvir között találjuk, ${ }^{11}$ 1582-1604 között többször volt városi számvevő és vonásigazgató, miközben

68 „1582 Sabato magno [ápr. 14.] domini centum electi congregati hoc modo decreverunt domino notario Luca Trausznero absente: Biro vram, Thanachiawal Jzennienek Notariusnak es hiuassak megh ha meg Jeó, Aggjak eleÿbe Doctor vramtol mynemeo walazt hozot Jstwan vram Ferencz vrammal egietembe. Eomaga tuggia vetket, dolgat, lassa miheóz tarcha magat. Mert az waros Jambor zolgalathiat meg bechwllye, es ertheny akariak ennek vthanna az eo maga akarattiat is. Es minden otalommal legien eo kegyelmek Nekje, ha az zwkseg kiwannia penigh esmeg meg talalliak az warostis feleolle." KvTanJk I/3. $252^{v}$. „Sabato post Georgii domini [ápr. 28.] centum viri convocati [...] predicto domino notario absente deliberaverunt: Mierthog a Gwlés eleotterwnk wagion, Tecczik eo kegyelmeknek warosul, hog ez alat a Notarius dolga legien haladekba, lassak mÿre valik dolga, kelle erette megis teorekednÿ Awag Nem. $\mathrm{Ha}$ hol olÿ Nehezen lezen dolga hog heliere Nem Alhat, hiuatalliara Nem mehet, [kiemelés PL] $A z$ vthan eó kegyelmeknek gongia lezen rea. Ez alat penig kj kj vigiazzon az gywles alat a theorwenÿre. Eó kegyelme ha az vraim keozzwl bochate, awag penig chak valakit eg bizonios Zemelt lewellel, awag ki ot lassan zallion, az eo kegyelmek itiletyre haggiuk." KvTanJk I/3. 253.

69 Pinnát Antal: Gerendi János és Eössi András. Irodalomtudományi Közlemények LXXIV(1970). 5-6. sz. 681; DÁNÉ: i. m. 82.

70 „Dominica proxima ante rogationum domini [máj. 13.] centum electi convocati, adhuc notario absente concluderunt: Mÿerthog eo kegyelmek warosul eg nehaniat tudnak Coloswary fiakot, kik elegnek latatnak az Notariussagnak tiztire, tecczet azert eo kegyelmeknek warosul, hog akÿ jobnak es alkalmatosbnak, versatusbnak tecczik affele vocatioban lennye, eo kegyelmek aggiak a waros eleybe, eo kegyelmekis zolnak feleólle, es vgian akkor a notariussagrol walo instructiotis keressek megh es hozzak eló, minemeó instructiowal attak az eleot valo notariusoknakis az notariussagnak tiztit, hog azon se kyweól se beleól ne hagion a notarius." KvTanJk I/3.253v.

71 KvTanJk I/4. 1. 
más városi megbízatásoknak is eleget tett. ${ }^{72}$ Számunkra legfontosabbként, 1586 márciusában a fejedelemi tábla előtt több fontos ügyben védte Kolozsvár érdekeit. ${ }^{73}$ Egyik ilyen ügy a város és Apafi Miklós között, a kolozsváriaknak Apafi káposztásszentmártoni birtokán való törvénytelen megvámoltatása okán kirobbant viszály volt. ${ }^{74}$ Másik ügyében azokat a városi bírákat és esküdteket képviselte, akiket Szentegyedi Somlyai Gergely fiskális direktor azért idézett a tábla elé, mert fejedelmi parancsot megtagadva, nem hajtottak be két kolozsvári személyen vallomástétel-megtagadásért kirótt bírságot. ${ }^{75}$ Harmadik ügyében szintén Kolozsvár érdekeit képviselte a városi magisztrátus és a szomszédos Szentmiklós település nemesei közötti évtizedes határrendezési perben. ${ }^{76}$ Szolgálatait a város méltóképpen megjutalmazta, novemberi elszámolásai szerint a sáfárpolgár a tanács utasítására 75 forintot utalt ki számára. $^{77}$

Emellett élete végéig tagja maradt a kolozsvári centumvirátusnak, még 1604-es katolizálását követően is folyamatosan feltűnik a neve a százférfiak listáján. ${ }^{78} \mathrm{~A}$ tanács többször igénybe vette szakértelmét bonyolult jogi kérdések megoldása kapcsán. Ilyen volt az a fejedelem elé fellebbezett jogi vita, mely 1587-1588 folyamán folyt a százférfiak tanácsán belül Ötvös András onnani kizárását követően. A konfliktus során Trauzner 1588 áprilisában Kolozsvári Márton deák, Pulacher István, Vicei Gáspár és mások társaságában a fejedelem előtt védelmezte a város régi rendtartását. ${ }^{79} 1590$ januárjában pedig - Budai Tamás, Pulacher István és Vicei Gáspár mellett - őt is felkérték, hogy bonyolult jogi ügyleteknél segítse a városi közügyigazgatók tevékenységét. ${ }^{80}$

A vármegyei nemesi környezetben, majd 1593-tól az országos politikában való egyre hangsúlyosabb jelenléte ellenére továbbra is vállalt szerepet városa életében. 1592, 1597 és 1598-ban is kapott 50-50 forintot a város sáfárpolgárától, feltehetően a város érdekében végzett ügyvédi ténykedéseinek honorálására, ${ }^{81} 1598$ végén pedig adószámvevő volt. ${ }^{82}$ Az Ötvös András személye körüli konfliktusban a város még 1593-ban is tanácsért fordult hozzá, 1594ben és 1597-ben pedig a fejedelemnél járt közben az ügy megoldása érdekében. ${ }^{83} 1602$ márciusában az országos politikától némiképp félrevonult Trauzner a városi tanács kérésére részt

72 Számvevő: 1582-1583, 1585-1589, 1601-1602, 1604; vonásigazgató: 1583, 1585, 1587, 1589. KvSzám 3/VI. 1; 3/X.1; 3/XXIII. 1; 3/XXIX. 1; 4/II. 1a; 9/XX. 1; 9/XXXIV.1; KvTanJk I/4. 1, 2v; $\mathrm{I} / 5.1 \mathrm{v}, 20^{\mathrm{v}}, 29,49^{\mathrm{v}}, 59^{\mathrm{v}}, 214^{\mathrm{v}}, 245$.

73 A városi számadások szerint Trauzner írásban számolt el a február 27-én kezdődő táblai terminuson a város pereire elköltött 92,5 forintról. KvSzám 3/XXVII. 13.

74 Kiss: Privilegii 623. sz.

75 Uo. 615, 616, 618, 624, 625. sz.

76 Uo. 627. sz.

77 KvSzám 3/XXVII. $16^{v}$.

78 1600-tól évente fennmaradt centumvirátusi taglistákon Trauzner neve mindig az elsők között szerepel. KvTanJk I/5. 188, 190, 201, 217, 233v , 247; I/6. 3, 23, 45.

79 KvTanJk I/5. 38v-39, 40-40v, 41v' РАКó 2010. 82-86.

80 KvTanJk I/5. 65.

81 50, illetve 100 forintot kapott minden évben a sáfárpolgártól. KvSzám 5/XI. 7; 7/IV. 8; 7/VI. 3; 7/XVI. 86.

82 KvTanJk I/5. 165.

83 KvTanJk I/5. 107v-108, 119v $156^{v}$; PАкó 2010. 82-86. 
vett a városi plébániaház leltározásában, ${ }^{84}$ a hónap végén pedig azok között volt, akiknek meg kellett találniuk annak a módját, hogy a város lakossága miként esküdjék hűséget a császárnak. ${ }^{85}$

Jogi ismereteit a város örökösödési és vagyonháramlási ügyekben is felhasználta. 1599 közepén fogott bíró volt egy kolozsvári ház megosztásánál, ${ }^{86} 1603$ májusában pedig a Brozer György házánál folyó osztály során Heltai Gáspár osztóbíró helyett intézkedett, aki személyes érintettség miatt nem tölthette be osztóbírói tisztségét. ${ }^{87} 1603$-ban a városra kirótt sarc miatt szedett adóba Monostor fertálybeli háza után 10 forintot fizetett. ${ }^{88} 1603$-ban letartóztatták, de szabadulása után is tevékenykedett. Május elején újra egy vagyonosztálynál találkozunk a nevével, ${ }^{89} 1604$. november 26-án számvevőnek nevezték ki, 1605. februárjában pedig a centumvirátus, másik hét társával együtt, beválasztotta abba a szakértői csoportba, melynek a nyolc osztóbíróval, illetve a bíró által kinevezett négy esküdtpolgárral együtt a városi öröklés problémás kérdéseiben kellett megoldásokat találnia. ${ }^{90}$

Prókátori tevékenységéről klientúrája alapján, ${ }^{91}$ továbbá mivel perei során Kolozs és Torda vármegyék bíráskodási fórumai mellett a fejedelmi tábla és az erdélyi unitárius szuperintendens ítélőszéke előtt is többször megfordult, ${ }^{92}$ állíthatjuk, hogy Trauzner kiemelkedő jogi felkészültséggel rendelkező, a fejedelemség igazságszolgáltatási hierarchiájának minden szintjén otthonosan mozgó, országosan elismert ügyvéd volt. ${ }^{93}$ Jegyzői gyakorlata mellett múveltségére és alapos jogi felkészültségére támaszkodó prókátori tevékenysége is meghatá-

84 KvTanJk I/5. 204v.

85 KvTanJk I/5.205v.

86 KvTJk II/9.345a.

87 RNLtKol, Asztalos céh iratai, Jegyzőkönyvek, nr. 2. 27v.

88 KvSzám 9/XXIV.3.

89 RNLtKol, Asztalos céh iratai, Jegyzőkönyvek, nr, 2. 27v.

90 KvTanJk I/5. 251v. - DÁNÉ: i. m. 87-88.

91 A Gerendi család tagjai (DÁNÉ: i. m. 82-83; ErdKáptJk 566-568, 587. sz; ErdKirKv VII. 3. 784785. sz. A szakirodalomban említett adatok mellett 1589-ben Gerendi György gyermekeinek: Pálnak és Borbálának nagybátyjukkal, Medgyesi Miklóssal anyai ági örökségük felett folytatott perükben is szerepelt prókátorként. MOL, A Gyulafehérvári Káptalan Országos Levéltára, F 4 - Cista Comitatuum [a továbbiakban F 4], Comitatus Alba, Cista 3, fasc. 5, nr. 18.) mellett Kovacsóczy Farkas és testvére János (ErdKáptJk 634. sz.), bátosi Tímár Pál marosvécsi tiszttartó (KmProt IX. 190-191.), Sulyok János (ErdKáptJk 900. sz.), háportoni Forró János Fehér vármegyei ispán (MOL F 4, Comitatus Alba, Cista 1, fasc. 5, nr. 15.), illetve Szerdahely mezőváros lakóinak is prókátorkodott (ErdKirKv VII. 3. 846. sz.).

92 1592-ben Gerendi János testvérét, Annát, majd Peterdi András szavai prédikátort, 1593-ban Sövényfalvi János deák ügyét képviselte az unitárius szuperintendens széke előtt, 1596 elején pedig lánytestvére képviseletét látta el ugyanott. UnitJk I. 24, 32, 40-41, 114-115. Gerendi Anna ügyét lásd: Kénosi Tőzsér János-Uzoni Fosztó István: Az erdélyi unitárius egyház története. I. Kvár, 2005 (Az Erdélyi Unitárius Egyház Gyüjtőlevéltárának és Nagykönyvtárának Kiadványai 4/1). 774.

93 A vármegyei nemesség közötti elismertségét az is bizonyítja, hogy Gerendi Pál - Angyalosi János, Kolozsvári János és Királyfalvi János mellett, akik mindannyian kiváló ügyvédek, a kancellária és a kincstári igazgatás jelentős szereplői voltak - őt is gyermekei testamentáriusának nevezte meg. Horn Ildikó: Gerendiek a kora újkorban = Uő: Tündérország útvesztöi. Tanulmányok Erdély történelméhez. ELTE-BTK, Bp., 2005. 113. Halála előtt fél évvel, 1608 februárjában, kápolnai Bornemisz- 
rozó volt karrierje alakulására. ${ }^{94}$ A városi magisztrátus tagjai valószínúleg még jegyzősége idején meggyőződtek jogi jártasságairól, ezért igyekeztek azt a városi közösség számára kamatoztatni.

Bélteki Sámuel deák prókátori tevékenysége szintén a városhoz köthető. Horvát Imréhez hasonlóan, ő is kolozsvári származású volt, és karrierjét ugyancsak a központi kormányzatnál kezdte. 1586-ban kisebb kancelláriai íródeák volt, ${ }^{95}$ 1589-ben a fejedelem ugyane beosztásában teljesített szolgálatait jutalmazva utódaival együtt megnemesítette és címert adományozott neki. ${ }^{96} \mathrm{Ez}$ idő tájt már foglalkozott prókátorkodással: 1588-ban a Bánffyakat képviselte a fejedelmi tábla előtt, ${ }^{97}$ az 1589. február 23-án kezdődött törvényszak alkalmával pedig Bogáthy András és Boldizsár ügyét képviselte a radnóti Kendi Ferenc tanácsúr és Küküllő vármegyei föispán elleni jogvitában. ${ }^{98}$ Ekkortájt képviselte alsójárai Bagaméri György nemes ügyét is Torda vármegye ítélőszéke, majd fellebbezés során a fejedelmi személyes jelenlét bírósága előtt. Ôt féltestvére, Lupsai Menyhárt meggyilkolásával vádolták és ítélték fej- és jószágvesztésre. ${ }^{99}$ 1590-ben háportoni Forró János nevében is eljárt annak bodolai ősi jószága felett folytatott perében. ${ }^{100}$ Hírneve a székelyek közé is eljutott, ugyanis valamikor az 1590-es évek folyamán nyújtódi Sete György Sennyei Pongrác, a várhegyi vár kapitánya előtt tett ügyvédvalló levelében Tordai János deák, Sámsondi András, székelyvásárhelyi Köpeci János, bongárdi Pistaki Lukács mellett őt is prókátornak fogadta. ${ }^{101}$

Az említett 1589. februári táblai törvényszak alkalmával nemesi kliensei mellett Kolozsvár nevében is tevékenykedett. A kolozsvári magisztrátusnak Apafi Miklóssal a káposztásszentmártoni vámszedés kapcsán kialakult jogi konfliktusában ő vette át Pistaki Lukácstól a város jogi képviselőjének a szerepét, és maradt a város képviselője a per 1592. februári sikeres lezárásáig. ${ }^{102}$

sza Boldizsár tanácsúr és Fehér vármegyei ispán is őt, Mindszenti Benedeket és Angyalosi János nevezte meg testamentáriusainak. KmProt XVII. 10 $10^{\mathrm{r}}-11^{\mathrm{r}}$.

94 Szamosközy István tudománya és bölcsessége révén elhíresült embernek nevezte, Giovanni Argenti jezsuita gazdag múveltségét, számos tudományban való jártasságát, de legfóképpen kiemelkedő jogi múveltségét, Giorgio Basta generális pedig az erdélyiek között kivívott tekintélyét és rendkívüli tájékozottságát dicsérte. BaLÁzs: i. m. 111,113; DÁNÉ: i. m. 84.

95 MOL, F 4, Comitatus Alba, Cista 3, fasc. 1, nr. 18 (Bogdándi Zsolt adata); MOL, P 702 - Wesselényi cs lt (a továbbiakban P 702), 3. doboz, 1. tétel, 45. (Az adatra Fejér Tamás hívta fel a figyelmem.)

96 ErdKirKv VII. 3. 978. sz.

97 RNLtKol, Függőpecsétes oklevelek gyüjteménye, nr. 29.

98 RNLtKol, Haller cs 1t, 45. csomó, 3 $3^{\mathrm{r}-4^{\mathrm{v}}}$. (Az adatra Szabó András Péter hívta fel a figyelmem.)

99 1568-ban mindkettőjük neve szerepel alsójárai Keresdi Dénes által vallott prókátorok között, 1578-ban mindketten vajdai emberként jelennek meg Báthory Kristóf vajda tanúvallatást elrendelő parancsában, 1579-ben pedig Bagaméri neve feltúnik Hosszúaszói Mihály és felsőjárai Hesdáti Márton ügyvédvalló levelének prókátornévsorában is. Kiss: Privilegii 500,579, 592. sz. A gyilkosság minden bizonnyal 1588. december 11-e előtt történt, ugyanis ekkor már az áldozat kiskorú lányának új gyámot jelölnek. ErdKirKv VII. 3. 856. sz. A per idejéről annyit tudunk, hogy a fejedelmi személyes jelenlét bírósága döntését az 1592. márciusi törvényszak idején hozta meg. KmProt XII. 108-111.

100 MOL, F 4, Comitatus Alba, Cista 3, fasc. 1, nr. 18.

101 MOL, P 702, 3. doboz, 1. tétel, 116.

102 Kiss: Privilegii 634a, 644, 657. sz. 
Ami további Kolozsvárhoz köthető ügyvédi tevékenységét illeti, a városi törvénykezési jegyzőkönyveknek egy 1591-es, nem egészen egyértelmú adata alapján azt feltételezzük, hogy városi polgárok ügyében is vállalt szerepet. ${ }^{103}$ Továbbá 1596 szeptemberében Beuchel András, Rot Tamás, Schmelzer Lőrinc és Filstich Péter társaságában fogott bíró volt Szentmiklósi Ötvös Gergely és felesége, Filstich Borbála közötti osztozás során. ${ }^{104} \mathrm{Ha}$ a város polgári bírósága előtti szereplése egyelőre meglehetősen gyéren dokumentált, annál több adat van az unitárius szuperintendens ítélőszéke előtti szerepléséról. 1592 vége és 1597 eleje között ugyanis több kolozsvári és vármegyei személy képviseletében jelent meg. Megrendelői között volt Vicei Erzsébet, Brozer Tamás lánya: Anna, Nyári Márton és mások. ${ }^{105}$

Prókátori karrierje csúcsának egyelőre azt az 1592-es esetét tekinthetjük, melyben Királyfalvi János fiskális direktor nevében járt el a fejedelmi tábla előtt. ${ }^{106} \mathrm{Az}$ ügy azért érdemel kiemelt figyelmet, mert Bélteki a per során három külön szerepkörben mutatkozott: 1586-ban kisebb kancelláriai íródeákként utasítást kapott tanúvallomások bevételére, 1590-ben a felperes képviselőjeként jelent meg a fejedelemi tábla előtt, 1592-ben pedig a fiskális direktor mint perbeavatkozó nevében védte a kincstár érdekét. Lényegében tehát egyetlen per során betöltött szerepei a kora újkori sikeres prókátori életutak egyik tipikus esetét rajzolják ki, ti. a kancelláriai írnokoskodás során a gyakorlati jogban szerzett ismereteit vármegyei nemesi környezetben kamatoztató ügyvéd karrierjét, akit eredményes tevékenysége a központi hatalom figyelmébe emelt.

Béltekiről elmondhatjuk tehát, hogy a gyakorlati jogi műveltségben a fejedelmi kancellárián pallérozódott kolozsvári származású íródeák ismereteit a prókátorkodás területén is sikeresen kamatoztatta. A vármegyei prókátorok körében szerzett hírnevét mutatja, hogy abosfalvi Radvánczy Márton ítélőmester másolati könyvének egy, valamikor 1594 és 1599 között keletkezett, ügyvédvalló levele olyan ismert ügyvédekkel szerepelteti együtt, mint Királyfalvi János, Trauzner Lukács, bongárdi Pistaki Lukács, Köpeci János, szőkefalvi Sámsondi András, Laskai János vagy Pápai Dániel. ${ }^{107}$ Kliensei között megtaláljuk a Küküllő, Torda és Fehér vármegyékben birtokos Bogáthy Andrást, Belső-Szolnok vármegyei fôispánt, Bogáthy Boldizsár marosszéki királybírót, vagy Suky Péter nemest. De előkelő kolozsvári polgárok is többen voltak megrendelői között. Az ő esete is azt mutatja, hogy Kolozsvár magisztrátusa - bevett szokásaihoz híven - azt követően alkalmazta ôt is városi fontos pereinek képviseletére, miután mind a kancellárián, mind a vármegyei szedrián, vagy éppen a fejedelmi tábla előtt már tanúságot tett jogi képességeiről és rátermettségéről.

103 KvTJk II/8. számozatlan lap a 171. oldal után.

104 UnitJk. I. 135-136.

105 UnitJk I. 31-34, 38, 61, 67, 86, 93, 101, 139-141.

106 MOL, F 4, Comitatus Alba, Cista 3, fasc. 1, nr. 18.

107 KmProt XII. 1. 


\section{ÖSSZEGZÉS}

A fennebb bemutatott és más ismert, de jelen írásban nem részletezett, ügyvédi életpályáknak a vizsgálata azt mutatja, hogy a gyakorlati jogban jártas, rátermett prókátorok megbecsült tisztségviselőknek számítottak a 16. század végi Kolozsváron. Származásuk tekintetében több mint kétharmaduk született Kolozsváron. Tevékenységük áttekintése alapján elmondható, hogy a magisztrátus a város különféle jogi ügyleteinek a megoldására jól kitapintható és következetesen alkalmazott szempontok szerint válogatta meg embereit. A várost mint közösséget, annak vagyonát és függetlenségét érintő, kívülről jövő fenyegetésekkel szembeni kiemelt fontosságú ügyeiben - ti. a fejedelmi tábla elôtt más törvényhatóságokkal viselt birtokperek vagy a városi kiváltságok megsértői ellen indított eljárások során - kizárólag jól képzett, jogi ismereteiket a fejedelmi kancellárián vagy külföldi egyetemeken szerzett, az ország legmagasabb ítélkezési fórumainak peres eljárásaiban is jártas és országos hírnévvel rendelkező prókátorokat foglalkoztatott. Közöttük egyaránt találunk városi, illetve vármegyei származású személyeket, akik azonban mindannyian a városi kereteken túllépő, országos ismeretséggel, hírnévvel rendelkeztek.

A város belső rendjét és a lakók személyi vagy vagyoni biztonságát érintő ügyei esetében azonban kivétel nélkül kolozsvári városi környezetben szocializálódott, a város törvényeit és a helyi szokásjogot behatóan ismerő, a prókátorkodás területén már gyakorlattal és széles városi klientúrával rendelkező polgárokat foglalkoztatott. Nagyrészük családi környezetben szerezte prókátori tudományát, de voltak a fejedelmi kancellárián pallérozódott ügyvédek is. Noha többségük eleve a város elókelő családjaiból származott, városi prókátori tevékenységük tovább egyengette előttük a vagyoni és a társadalmi felemelkedés útját. Fontos városi vezető funkciók esélyes várományosaivá válhattak, házasságaik során a legbefolyásosabb városi famíliáknak válhattak a tagjaivá, ezáltal pedig széles társadalmi kapcsolathálót alakíthattak ki maguk körül. Mondhatni, hogy az egész városi elittel, ső́t akár az országos politika kulcsszereplőivel is kapcsolatba léphettek.

A prókátorság megteremthette tehát a sikeres karrierépítés lehetőségét, de amint Igyártó György esete példázza, a bukás lehetőségét is fenntartotta. Abban, hogy másoktól eltérően Igyártónak nem sikerült sem a város vezetô testületeibe bekerülnie, sem a városi kereteken túllépnie, abban jelleme és magatartása akadályozták ôt meg. Annak ellenére, hogy a jogi kérdések megoldásában otthonosan mozgott, magánéletének és szakmai tevékenységének gyakori botlásai akadályozták előhaladását.

\section{ADVOCATES (PROCURATORES) IN CLUJ (KOLOZSVÁR) IN THE LATE $16^{\mathrm{TH}}$ CENTURY}

\section{Keywords: Transylvanian Principality, early modern Cluj, judicial activity, legal intelligentsia, advocates}

Based on records preserved in the town archives, the first part of the study focuses on the general presentation of the institution of the advocates in Cluj at the end of the $16^{\text {th }}$ century. In the second part the author details the carriers of György Igyártó, János Kalmár, Imre Horvát, Lukács Trauzner and Sámuel Bélteki, reflecting on the career possibilities of the early modern advocates. The analysis points 
out that in Cluj at the end of the $16^{\text {th }}$ century the able advocates were among the most respected officeholders of the town. In cases which prejudiced the community of the town, the wealth and goods, or the liberties of the town as a whole the magistrates hired only advocates, who had gained their judicial knowledge in the chancellery of the principality or at foreign universities, who had experience at all levels of the judicial institutions of the country, and had a good reputation countrywide. On the other hand, in the cases concerning the internal peace and order of the town, the material stability and personal safety of its citizens, the town leaders worked exclusively with advocates from Cluj, who were familiar with the laws and the consuetude of the town, and whose activity was highly appreciated among the citizens. The analysis revealed as well that in the case of the latter their activity as advocates facilitated their vertical mobility. At the same time, as György Igyártó's case exemplifies, although the office of an advocate could offer the perspectives of a great carrier, it could also lead to breakdown.

\section{PROCURATORI (AVOCAȚI) ÎN CLUJ ÎN ULTIMELE DECENII ALE SECOLULUI AL XVI-LEA}

\section{Cuvinte-cheie: Principatul Transilvaniei, Clujul premodern, activitate judecătorească, intelectualitate juridică, procuratori (avocați)}

Bazându-se pe informații păstrate în arhiva orașului, prima parte a studiului oferă o prezentare generală a instituției procuratorilor din Cluj de la sfârșitul secolului al XVI-lea, după care prin analiza carierelor lui György Igyártó, János Kalmár, Imre Horvát, Lukács Trauzner și Sámuel Bélteki reflectă asupra posibilităților pe care le oferea „meseria” de avocat. $\mathrm{Cu}$ ajutorul datelor adunate autorul a reliefat că în Clujul sfârșitului de secol XVI avocații pricepuți în problemele juridice erau considerați funcționari respectați ai orașului. În cazul proceselor care primejduiau comunitatea orășenească, averea ori libertățile urbei magistratul a angajat întotdeauna avocați reputați, bine instruiți, care și-au însușit cunoștințele juridice în cancelaria țării, sau la universități din străinătate și care aveau experiență la toate forurile de judecată ale țării. În procesele privind ordinea internă a orașului, siguranța materială și personală a locuitorilor în schimb magistratul a angajat în exclusivitate avocați socializați în mediu clujean, familiarizați cu cutuma locală și cu legile orașului, și care aveau deja o clientelă orășenească extinsă. Analiza a reliefat de asemenea că, mai ales în cazul celor din urmă, avocatura le-a facilitat ridicarea pe scara socială și economică a orașului, sau chiar a țării. În paralel însă, cazul lui György Igyártó a evidențiat faptul că avocatura putea oferi într-adevăr perspectivele unei cariere strălucite, dar și decăderea. 